\title{
Interpretations of Emanuel Swedenborg's image of the afterlife in the novel Oneiron by Laura Lindstedt
}

https://doi.org/10.30674/scripta.85054

TIINA MAHLAMÄKI and TOMAS MANSIKKA

VERTAISARVIOITU
KOLLEGIALT GRANSKAD
PEER-REVIEWED
www.tsv.fi/tunnus

This article discusses the relationship between Western esotericism and literature. As an example of a secular author who uses and benefits from esoteric texts, ideas and thoughts as resources in creating a literary artwork, the article analyses Laura Lindstedt's novel Oneiron. A Fantasy About the Seconds After Death (2015). It contextualises the novel within the frames of Western esotericism and literature, focusing on Emanuel Swedenborg's impact on discourses of the afterlife in literature. Laura Lindstedt's postmodern novel indicates various ways that esoteric ideas, themes, and texts can work as resources for authors of fiction in twenty-first century Finland. Since the late eighteenth century Swedenborg's influence has been evident in literature and among artists, especially in providing resources for other-worldly imagery. Oneiron proves that the ideas of Swedenborg are still part of the memory of Western culture and literature.

Listen up, ladies. Once there was a mystic who was sometimes called a philosopher ... he described the afterlife in a way that slightly resembles where we are now. (Lindstedt 201 5: 209-IO). ${ }^{1}$

\section{From Oneiromantia to Oneiron}

In I783 a book entitled Oneiromantia, or the Art of Interpreting Dreams (Swedish original: Oneiromantien, eller konsten att tyda dröm[m]ar) was published anonymously in Stockholm. It was written by two followers of Emanuel Swedenborg (I688-1772), the brothers August Nordenskjöld (also Nordenskiöld, I754-92) and Carl Fredrik Nordenskjöld junior (I756-I828). They were born in Finland, which at the time constituted

1 All English translations of the novel are from Lindstedt 2018 (transl. Owen F. Witesman), but page numbers are from the original publication of 2015 . We use the electronic version of the translated novel which lacks page numbers. 
the eastern region of the kingdom of Sweden. As editors of Swedenborg's manuscripts, they were amongst the earliest of the Swedenborgians in the I 770 s, having especially close ties to England and the growing numbers of followers of the Swedish visionary there. Within this emerging movement August Nordenskjöld, who also made a career as a court alchemist to King Gustavus III, travelled frequently to England and delivered an address at the first Swedenborgian conference, held in London in I789 (Paley I 979; Schuchard 1992; Rein 1939; Smithson I841; Siukonen 2000; Mahlamäki and Mansikka 2oro).

Meanwhile, in Sweden and Finland the publication of works by Swedenborg had been placed under censorship by a royal decree. As a dream dictionary, Oneiromantia was the first work to challenge these restrictions by disseminating Swedenborgian ideas in a book on a popular subject of the time. As a 'pseudo-Swedenborgian' piece of writing, Oneiromantia brings together central topics of Swedenborg such as love and light, articles on various philosophical and theological subjects, and more specific entries such as 'snow', 'pig', or 'shoes', interpreted through the doctrine of correspondences - a central principle in Swedenborg's thinking and in Western esotericism at large. In Jane Williams-Hogan's words, Oneiromantia ' gives a good overview of the interests of occultists and theosophists of that period'. It also had the effect of encouraging Swedenborgians to publish Swedenborg's writings outside Sweden (Sjödén r 995: 66-7; Williams-Hogan 2016: 539; Blåfield 2008; Oneiromantien I783, I-II).

Some 230 years later a Finnish author, Laura Lindstedt (b. 1976), has a dream, or a vision, in which she is given the key word and title for her forthcoming novel, Oneiron (Oneiron. A Fantasy About the Seconds After Death, 2015). Lindstedt's Oneiron takes place in a dream-like emptiness, a white space or void. Only whiteness exists, and into this emerge seven women ${ }^{2}$, one by one, as voices in the emptiness: Shlomith, Polina, Wlibgis, Rosa, Imaculada, Nina, and Ulrike. As characters and personalities, representing various ethnicities and religious backgrounds, they do not question who they are, but rather what has happened to them, and where they have arrived. They only have the clothes they are wearing with them; no memories concerning

2 Compare the seven women with the seven brothers; as the voices of two authors mirroring their different historical settings, the nature of enchantment, and spirit-world. 
their respective deaths. At first, they have difficulties in understanding each other, because of language barriers, but proceed later on to a state where they can communicate by connecting their minds. As to their appearances, they are not only visible, but tangible in the sense that they can touch each other, having thus retained their gendered and human forms. They are constantly present to each other, which means they cannot hide anywhere. They also become successively loosened from their material and vital embodiments; at some point they take notice that they have stopped breathing, no longer experiencing corporal sentiments, such as the ability to feel pain or pleasure, hunger or thirst. Finally, their minds desire to move forward and to give up; with the assistance of the word 'Oneiron' they confront the events that will lead to their deaths and departure from the emptiness. Each one encounters her own death and moves forward with the help of the others - where to is left open. What remains of them in the world are memories, presented in Oneiron in form of newspaper articles, obituaries, and necrologies published after their deaths.

While the two books Oneiromantia and Oneiron have little in common save for the word Oneiron, Lindstedt's novel can be discussed to good effect from at least four viewpoints. First by locating it within the larger field of Western esotericism and literature. Secondly by discussing it within a distinctly Swedenborgian literary reception and culture in Finland, in part related to the historical context of Oneiromantia. Thirdly by discussing the novel's other-worldly structure and features in relation to a Western esoteric and Swedenborgian afterlife in particular. Finally the article will point out that while the Swedenborgian afterlife plays a role in the novel, its primary characteristic may be defined - as reflecting the author's preferences - as a magical tribalism.

\section{Western esotericism and literature}

Western esotericism is in many respects a thoroughly literary phenomenon. While esotericism may utilize rational, theological or even scientific discourse, as in the case for instance of Swedenborg or Anthroposophy, esoteric ideas transmit alike through fiction and poetry. Like religious discourses, esotericism also uses grand narratives, myths, allegories and symbols which can more adequately be expressed within fiction and poetry. It is therefore no surprise that fiction - poetry, drama, novels - may not only contain, but actually also function as, reservoirs of esoteric knowledge (see e.g. Versluis 
2004: $3-5$ ). Of those literary works that hold the status of imparting esoteric philosophy, Edward Bulwer-Lytton's novels Zanoni (I 842) and Vril: The Power of the Coming Race (1871), amongst others, are often referred to. Bulwer-Lytton's works were endorsed in both Theosophy and Anthroposophy, as in schools of ritual magic, and have subsequently been discussed within much of twentieth-century Western esotericism (see e.g. Gilhus and Mikaelsson 2013: 454). Thus, as Christina Ferguson (2019: 100) contends, popular literature is not simply 'a passive reflection of enduring public opinion towards esotericism; it might also, as occultists and anti-occultists alike have recognized, be its active producer'(see also Versluis 2004: 135-6). While Bulwer-Lytton employed historical novels as a medium for imparting his ideas and philosophy, later occultists also resorted to popular fiction besides their non-fictional works including, for instance, Helena Petrovna Blavatsky, Emma Hardinge Britten, Arthur Edward Waite, Charles Leadbeater, Aleister Crowley, and Dion Fortune (see also Gilhus and Mikaelsson 2013; Faxneld and Fyhr 2010: I6-I7; Bogdan 2020). Although works of popular fiction written by'esoteric' authors may seldom become real bestsellers ${ }^{3}$, they reach much wider audiences than works of non-fiction, as they utilise different genres, such as romance, ghost stories, fairy tales, science fiction, and detective novels (Ferguson 201 9: 99). Finally, the genre of esoteric literature in which a division between esoteric and exoteric is maintained could be indicated, which is thus communicating a double message: what for common readers appears as mere fiction, for readers aware of the esoteric underpinnings the text conveys imageries of various occult trajectories. In these cases the message received depends on the reader's ability to understand the layers of metaphors and symbols employed (Bauduin and Johnsson 2018: 20; Kokkinen et al. 2020: 24I-2). Researchers may here interpret either the intention of the author or the intention of the reader; for what purpose the novel is written and for what purpose it is read. ${ }^{4}$

As Christine Ferguson (201 9: I00-I) points out, the early theosophists knew that fiction has to be both entertaining and imaginatively stimulating.

3 Examples of bestseller esoteric novels would be, for instance, Bulwer-Lytton's The Last Days of Pompey (1834); in the twentieth century, for instance, The Devil Rides Out (1934), and other novels of Dennis Wheatley.

4 To this category could be added a wide range of works, such as Liber Novus or The Red Book (publ. 2009) of C. G. Jung, a writing on which Jung remarked: 'To the superficial observer, it will appear like madness' (see Corbett 2009). 
This awareness however has not always been beneficial for literature: some writers of 'occult-themed fiction' she continues, and 'particularly those publicly associated with theosophical and ufological currents, have eagerly embraced the propagandistic potential of popular fiction, sometimes to the detriment of its aesthetic quality' (see also Gilhus and Mikaelsson 2013). Ferguson writes that there are three purposes for esoteric popular fiction: proselytization, entertainment, and canon formation. Some of them are manifest when 'occult thinkers identify certain critically acclaimed and/or enduringly popular works of literature' as more than mere pieces of art; characterising them as 'encoded vessels of esoteric wisdom: in doing so, they claim the attendant cultural capital of such texts for their mystical worldviews' (Ferguson 2019: 102). An example of this may be seen, for instance, in the publication and critical reception of Dan Brown's The Da Vinci Code in Finland. The main journal of the popular esoteric scene, Ultra, published no less than three reviews of the book, which were all in agreement that it revealed hidden truths (Ramstedt 201 8; Ramstedt and Moberg 2020: 2603). In cases like this, where popular fiction purports to unveil mysteries by decoding esoteric or religious symbols, riddles or clues, the act of reading may be seen as a form of spiritual practice in itself (see Ferguson 20 19: I03; Versluis 2004: 13).

Another form of collaboration between literature and esotericism is in the reference to esoteric or occult texts within fictional narratives. These texts can be both 'authentic', as for instance in the references to actual historical works on magic in J. K. Rowling's Harry Potter series (I 997-2007), or 'fictional' as the Necronomicon in the novels of H. P. Lovecraft. In both cases, notwithstanding, they function as resources. By means of this interplay esoteric and occult persons, conceptions and ideas become familiar among consumers of popular culture. But while these 'dimensions of occultism' have, according to Ferguson, indeed been taken seriously within modernist studies, ${ }^{5}$ this is not yet the case within literary studies, in which esotericism (or occulture) and popular fiction have until relatively recently been left outside serious academic study. Finally Ferguson asks what can be achieved from 'a new form of literary occultural studies which combines expertise in both the emergence of esoteric currents and in the development

5 '...under whose aegis they have hitherto almost exclusively been examined'. Christine Ferguson (2019: 96) argues here against Tessel M. Bauduin and Henrik Johnson (2018: 3). 
of popular literary genres and markets. ${ }^{6}$ Such a methodology promises to correct previous approaches to occult fiction which have either minimized its literary texture or miscast its complex relationship to historical expressions of esotericism' (Ferguson 2019: 97-8). To be able to interpret occult fiction or art properly, researchers thus need acquaintance with relevant and specific currents and ideas, and also discernment concerning representations and interpretations of historical themes (Kokkinen et al. 2020: 245).

\section{The impact of Emanuel Swedenborg in art and literature}

Emanuel Swedenborg's position within Western esotericism is unconventional but highly important. ${ }^{7}$ As a versatile writer, the Swedish scientist and seer conveyed his thoughts through various literary genres, from scientific, philosophical and theological to mytho-poetical works. ${ }^{8}$ Far from being a magician, occultist or anything of that sort, in his person combines Lutheran piety with currents of mystical theology and Platonism. While influencing both art and literature, movements such as utopian socialism, transcendentalism and spiritualism, his legacy to modernity may be seen primarily in the articulation of a modern afterlife. The modern perception of heaven and the spirit world, as commonly represented in modern-day popular culture, could be shown to owe many, if not all, of its elements to Swedenborg. For this reason any discussions of the afterlife, in literature, philosophy or theology, seem to become by necessity also apprehensions of him, thus acknowledging his legacy in art and culture (see e.g. Williams-Hogan I 998, 2005; Lachman 2009). His impact on classical authors such as August Strindberg, Edgar Allan Poe, Charles Baudelaire, Jorge Luis Borges, William Blake, Feodor Dostoevsky, Selma Lagerlöf, and Arthur Conan Doyle is widely recognized and much researched (e.g. Versluis 2004; McNeilly 2005; Williams-Hogan 2008; Faxneld and Fyhr 2010). (201 8); see also Versluis 2004: 5; Kokkinen et al. 2020.

7 Of Swedenborg's life, career, and place within Western esotericism, see e.g. Williams-Hogan I 998, 2005; Smithson I 84I; Lachman 2009, and all the textbooks concerning the domain of Western esotericism.

8 Swedenborg wrote a creation poem (De Cultu et Amore Dei I 745) which is regarded as a landmark work in Swedish literature. Swedenborg I 988. 
In previous studies the authors of this article have published studies dealing with analyses of Swedenborgian themes in three Finnish authors. These studies included taking under some scrutiny Johan Ludvig Runeberg's Letters from an Old Gardener (1836-8), Aleksis Kivi's Seven Brothers (1870), and the literary oeuvre of Kersti Bergroth (I 886-I 975), who was a first-generation anthroposophist (Mahlamäki and Mansikka 20ı, 20I3; Mahlamäki 20I0, 20I4, 20I7, 20I8). The ways in which they drew inspiration from Swedenborg varies greatly. Whereas Runeberg was a poet representing nineteenth-century idealism and national romanticism (Mahlamäki and Mansikka 20IO, 20I3), Kivi used the literary devices of parody, travesty and irony in his novels and plays (Mahlamäki 2oro; Mahlamäki and Mansikka 2013). Bergroth in turn could be seen as a writer of fiction with a double message; novels that can be seen to be imparting different messages for different readers (Mahlamäki 20I4, 20I7). While Bergroth's spiritual or esoteric path was anthroposophical rather than Swedenborgian, there is concord and mutual confirmation between the two ideologies, being parts, so to speak, of a larger esoteric family (Mahlamäki 201 8). Of other Finnish writers of fiction that still await research regarding esotericism and literature, the names of Pekka Ervast, Helmi Krohn, Eino Krohn, and more recently A.W. Yrjänä and Heikki Kännö, could be mentioned (see Kokkinen et al. 2020).

Laura Lindstedt's Oneiron can be seen as a work of fiction that takes inspiration from certain currents of esotericism. Although Oneiron has been widely read - it sold over 40,000 copies in Finland and has been translated into several languages - it does not represent popular fiction strictly speaking, but a genre of the postmodern novel. We will interpret Lindstedt as a 'secular' author who uses, benefits from, and creates on the basis of esoteric texts and ideas as resources in producing a literary artwork. As with many other artists and authors taking inspiration from Swedenborg, Lindstedt also seizes on an interest in the liminal stages after death. In works of fiction it is not uncommon nowadays to find a list of references at the end, and Lindstedt lets us know what books she has read - amongst which are the Finnish translations of Swedenborg's De Nova Hierosolyma et Ejus Doctrina Coelesti (Elämän oppi uutta Jerusalemia varten 1934) and Clavis Hieroglyphica (2000), the last including a presentation of Swedenborg's life and influence in Finland by the visual artist and researcher Jyrki Siukonen.

As to Oneiron's depiction of the afterlife, it is notable that the author has not consulted the most exhaustive work of Swedenborg as regards the afterlife, namely his Heaven and Hell (De Caelo et Eius Mirabilibus...), which 
was translated into Finnish (Taivas ja Helvetti) in r940. This is also evident in the novel as a whole, as Swedenborg's views are not developed in more depth or detail. Nevertheless, by adopting Swedenborg as one of the voices in Oneiron, the author has chosen a thinker who in fact has contributed in a positive and emancipatory way to our modernist view of gender equality - in both society and the afterlife. To this we will return later on in the article. Perhaps also unwittingly, Lindstedt reiterates a somewhat outdated 'negative influence thesis' (Thorpe 20I : 2) concerning Swedenborg. This legacy, ascribed to the influence of Immanuel Kant, questions a simultaneous coexistence of rationality and spirituality, maintaining a kind of 'two outcomes' thesis: the scientist-seer should be regarded either a truthful witness or mentally deranged. However, as stock in trade points of view, this, as well as the numerous anecdotes of his life and conduct, as scientist, theologian, and visionary, are part of the world memory of Swedenborg. In art and literature one of his most enduring influences can be detected in perceptions of the immediate afterlife.

Oneiron thus compares to works such as, for instance, Jean-Paul Sartre's No Exit (1944), Lars Norén's Andante (2019), and Roy Andersson's movie Songs from the Second Floor (2000), which by various means illuminate possible conditions after death. An analysis of these works, as also of Oneiron, would point to various resemblances to the first stages of the afterlife described in Heaven and Hell. These descriptions have been the most read and commented upon in literature, as they provide the protocol for the specific modalities and orders that govern the afterlife. Thus, in various degrees, they are found employed in non-fiction, fiction and science fiction alike. However, as regards Swedenborg's descriptions of the more subtle regions, such as heaven, writers - especially those of a secular stance - have usually been more wary. With these terrains we enter areas of Christian theology and mysticism concerned with, amongst other things, transcendental love and will. To more fully grasp the afterlife of Swedenborg some of these historical and theological conditions will be highlighted next.

\section{Swedenborg's afterlife}

As Colleen McDannell and Bernhard Lang (200I: I 8 I-227) have shown, Swedenborg's heaven was the first modern afterlife. It is characterised by four aspects: first, only a thin curtain or veil separates the afterlife from earthly existence, and it starts immediately after death. Second, the afterlife 


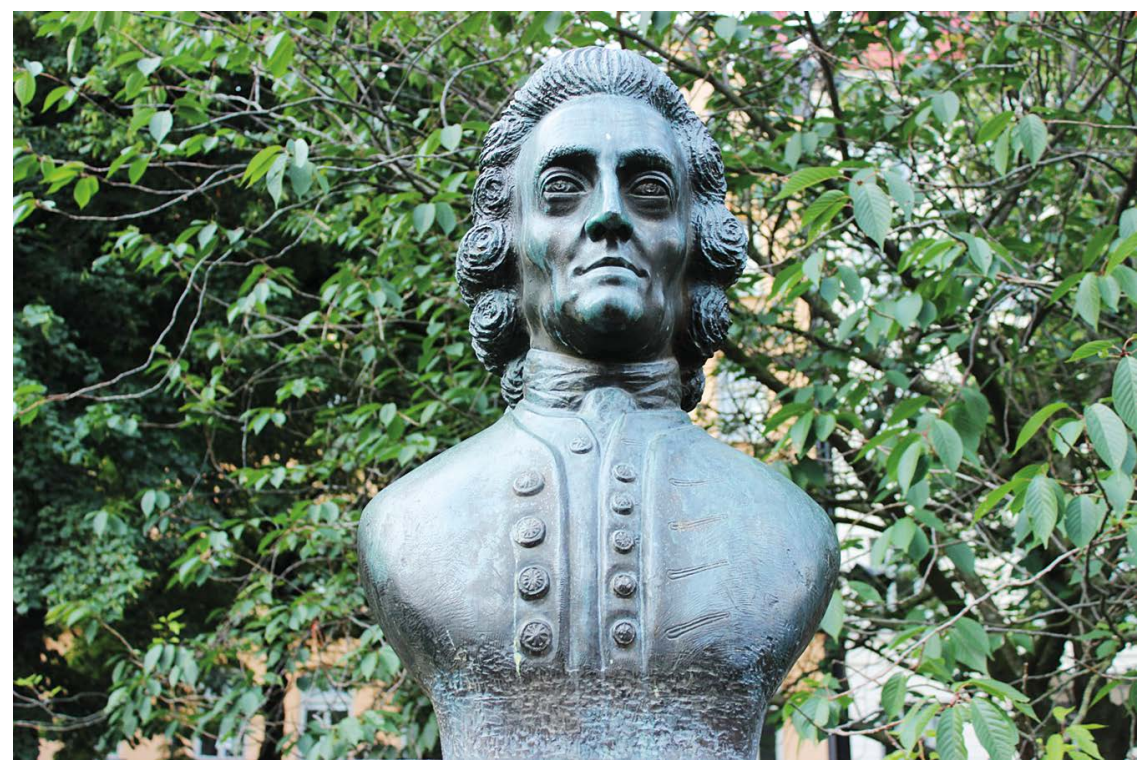

The statue of Emanuel Swedenborg in Stockholm. Photo by Tiina Mahlamäki.

is not seen as the opposite to earthly life, but a consequence and fulfilment of it. The third characteristic is that even though the afterlife and heaven are places of rest, the spirits inhabiting them are active and continue to develop spiritually. The fourth characteristic is that it emphasises human love, which manifests in various kinds of interhuman relationships. Within Western culture and esotericism this legacy manifests, as mentioned, in movements such as transcendentalism and spiritualism, as for instance in the works of Ralph Waldo Emerson (1803-82) and Henry James (1843-1916). More general characteristics include a universal order of correspondences, which in this article is illustrated by a logo- or phonocentricism that governs the spirit world. Lastly, and of particular interest to our subject, is the continuance of gender-specific identities in the afterlife.

Swedenborg's afterlife is profoundly anthropocentric, even to the degree that heaven has a human form (maximus homo). In the Swedenborgian universe people are primarily minds, guided by wills and affections, which are born, live and die, and finally resurrect in the afterlife. Humans do not reincarnate but are born only once, and after passing away settle in the afterlife, from which they eventually proceed to heaven or descend to hell. The immediate afterlife consists of three phases, of which the first closely resembles the earthly life. Here the spirits continue as they did in their previous lives, 
orientating themselves by their peculiar interests, affections and objects of love. The second phase is marked by an increasing transparency, in which the inner inclinations of the spirits become manifest to the others, making it impossible to hide behind their appearances. The third is the final preparation of the spirits as to their destinations and respective regions in heaven or hell (see Swedenborg 2010).

Swedenborg speaks of love as corresponding to will, in the sense that when humans are attached to virtues or vices, ideals, objects, or mere amusements, their love is also their will. There is, however, a heavenly will or love that humans partake in. In the afterlife the deceased spirits eventually become aware of this order, which is the correlation of their wills with the good and the true. The spirits will proceed to the various heavenly regions to the extent their souls are adapted to this unconditioned will. Thus, in the end, only unconditioned will or love will qualify the souls for the heavenly communities, whereas spirits with evil or narcissistic forms of love will inhabit various regions in hell, where they continue to execute their desires. Swedenborg depicts these dwellings as cave-like, dark and gloomy, suffused with toxic odours; when occasionally a beam of light enters an underground region, it blinds and terrifies the inhabitants (see Swedenborg 2010).

The primary tool for communication in the afterlife is speech. This applies not only among the spirits or the deceased, but among angels as well. Like human language, angelic language also 'is differentiated into words', Swedenborg writes (2010: \$235). Thus, different forms of speech are found on multiple planes in the spiritual universe. In heaven, he writes, all people have the same language:

They all understand each other, no matter what community they come from, whether nearby or remote. This language is not learned but is innate; it flows from their very affection and thought. The sound of the language corresponds to their affection and the articulations of the sound - the words, that is - correspond to the mental constructs that arise from their affections. Since their language corresponds to these [inner events], it too is spiritual, for it is audible affection and vocal thinking. (Swedenborg 2010: \$236)

From the viewpoint of the deceased in the spirit world, speech ascends from exterior to interior and becomes more perfect and universal in the regions of heaven. There, Swedenborg writes, the language 'is not a language 
of words, but is a language of ideas of thought; and this language is the universal of all languages' (Swedenborg 2o Io: § I637, 5272 ; see also Mahlamäki and Mansikka 20ro: 87; Mahlamäki 2018).

\section{A gendered afterlife, with a Finnish prelude}

When August Nordenskjöld attended the Swedenborgian conference in London 1789 , he shared among the participants information of a hitherto unknown diary by Swedenborg. The diary contained, as did also the work De Amore Conjugiali ( 1768 ) not yet translated from Latin, some seemingly explosive thoughts on marital and reciprocal love. These Nordenskjöld had interpreted and, seemingly, also applied to his life, as his own marriage had been notoriously unhappy (his wife did not share his affection for Swedenborg). ${ }^{9}$ Nordenskjöld had learned from Swedenborg that as gender identities continued in the afterlife, it would follow also that love and affection between human beings continued beyond the earthly life. In articulating this Swedenborgian view Nordenskjöld was ahead of his time, as he anticipated by half a century the views of Carl Jonas Love Almquist (I 793-I 866), the popular Swedenborgian novelist. Almquist heralded views of gender equality and non-marital relationships in bestseller novels such as Det går an (1839) ${ }^{10}$, inspiring contemporaries such as Runeberg and Zachris Topelius ( 18 1 8-98), and provoking more conservative minds such as Johan Vilhelm Snellman (I 806-8I), who wrote a critical reply in Det går an. En tafla ur lifvet. Fortsättning ( 1840 ). Almquist's views emerged largely from the modern, Swedenborgian perception of an afterlife in which gendered (heterosexual) relationships would not only continue, but also new partnerships and marriages would be instigated in the afterlife. Later in the century we find such views in, for instance, Aleksis Kivi's novels and plays.

In Swedenborg's platonic view humans long to find a partner, that is, a counterpart, in order to become whole (achieve conjunction). Those who

9 Nordenskjöld went so far as to suggest that in cases such as his, one would be allowed to take a mistress. Proposing that Swedenborgians should endorse concubinage, among conference attendants such as William Blake and his wife Catherine, passed from initial perplexity to subsequent silencing, and the episode was suppressed from all later histories of the Swedenborgian Society. Paley I 979.

10 Literally 'It will do'. Translated into English with the title Sara Videbeck and the Chapel (I9I9). 
have already found their partners will continue their relationship in the afterlife. Those who have not will eventually find a new and suitable partner out there. Moreover, those who have lived in unhappy relationships will distance themselves from each other and find new soulmates. The afterlife is a place where marriages occur frequently. This idea that gender difference and marriage, including separations, continue beyond death was a new notion in a long history of theology and Christian philosophy which had viewed the deceased as genderless. ${ }^{11} \mathrm{~A}$ modernist reading could readily interpret this Swedenborgian turn, not through the lens of fixed genders, but from its premises of interhuman relationships.

\section{Afterlife rituals and magic}

The afterlife of Oneiron is an existence of female identities. They gather in a ritualistic fashion around a wig - which has belonged to Wlibgis who had lost her hair due to cancer treatments - making it their campfire around which they tell stories about their lives and their last memories. They come to realise the campfire is not enough to protect them; they also need walls around them:

But where will they get walls? What will be the construction materials? Each has her clothes but not much else. Nothing beyond the odd little thing that happened to come with them when they left; something forgotten in the bottom of a pocket. So they start with the easiest thing and empty their pockets. They all have pockets except for Wlibgis, who is wearing ugly, green hospital pajamas.... The clothes are to become the walls, the boundaries of the rooms, and boundaries are what they need now, because without boundaries a person becomes a panoply of pirouetting panic. Like a child who gets everything she wants. For whom no verbal edifice of opposition is erected. (Lindstedt 2015: 167)

11 '[T]he notion that married partners will meet again in the other world and will belong to each other as married partners is not a common Christian notion at all. Even today, what predominates is the actual understanding of the early church and of Augustine that in the resurrection we will be genderless, all essentially identical. Swedenborg was the first to venture to propose the doctrine that gender differences and marriage continued beyond death into the other world.' Horn I 997: 22-3. 
After this ritualistic composing of a shelter or a home ${ }^{12}$ by means of their clothes, the women appear all naked, unable to hide their bodies from the others' gaze. They witness various female bodies: a pregnant body, an anorectic body, an overweight body, a body dried up due to cancer, a body of a teenage girl, a scarred body. The bodies are the same as during their lifetime, with the exception that they do not feel pain anymore, which is a relief for most of them.

From the outset Oneiron would

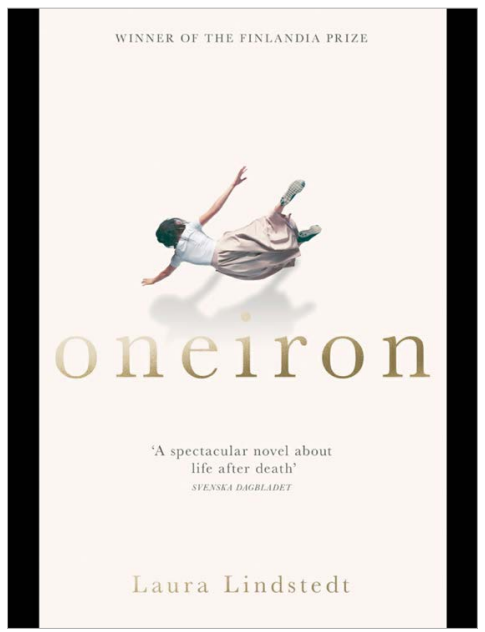
appear to share various common features with the Swedenborgian after-world. Fundamentally different however is the overall backdrop against which the other-worldly display is enacted. With no escape, they can experience privacy only by closing their eyes. In one passage Polina, by closing her eyes, retreats to a private imaginative state, and on opening them again confronts a reality where 'once again everything is harsh, shadowless, painfully white'. This spatial, or semi-spatial, feature makes the after-worldly existence both sinister and hostile, and something quite different from a traditional spiritual 'atmosphere': the bright light of meditational practice, the bardo of the Tibetans, the inner light of Christian mysticism. As the whiteness is maintained as an 'outer' principle in contrast to a private 'inner', the other-worldly fabric runs the risk of being a mere extension of mundane existence. Swedenborg, as Lucas Thorpe writes, 'believed that the spatiality and temporality of objects of experience were due to our mode of perception and not due to the nature of the objects themselves' (Thorpe 20 I I: 2).

In the Swedenborgian afterlife the surroundings adjust to one's state of mind; existence being as pleasant or unpleasant it is projected to be. There is no 'matter' outside the minds; a dark and destructive mind will engender dark

12 In his groundbreaking work Crossing and Dwelling (2006) Thomas Tweed defines religion as situating people in time and space, positioning them in the body, the home, the homeland, and the cosmos. He sees the importance of religion in marking boundaries and constraining terrestrial, corporeal, and cosmic crossings - glimpses of this can be seen in the homemaking process of women in Oneiron. 
and destructive surroundings, while a lovable or delightful mind engenders lovely and pleasing surroundings (Swedenborg 2010). Traditional, religious afterlife descriptions are conventionally allegorical and anagogical: 'whiteness' or 'light' are metaphors, for example, for clarity, goodness, pureness and progress, while darkness stands for opaqueness, evilness stagnation. While nakedness would imply in Swedenborg's second-phase afterlife that the inner thoughts and inclinations of the deceased have become manifest, for the characters in Oneiron this merely appears to mean that they expose, in some humiliating fashion, their naked bodies to each other.

Without variables such as night and day, sleep and wakefulness - even heartbeats - the only way for the women to measure or pass time is by means of conversation. Speech, or words, is what ultimately constitutes reality and, eventually, the only thing they have left:

Now everything else is gone, everything except words. Conversation, no matter how clumsy it is, no matter how loaded with misunderstanding, maintains time, nurturing them, helping them remain people in some incomprehensible way. Talking, prattling, even arguing: it isn't a question of entertainment. Words offer them safe chains, something to keep them afloat, causes and effects, although not yesterdays or tomorrows, which have become meaningless expressions, but continuums, continuums all the same: that is what speech gives them. The evergreen groves of memory, from which they can draw both the feeling of the past and the expectation of the future. (Lindstedt 2015:202)

The afterlife is not merely phonocentric, but also and at its base logocentric: the word 'Oneiron' has the power to push the women forward towards redemption. Logocentrisms of various kinds are deeply rooted in our Western culture; both in our Jewish-Christian roots as well as preChristian mythical cosmologies. As Jenni Råback (2018) notes, Lindstedt at times invokes 'Kalevalaesque otherworldliness' in her use of alliterations. Lindstedt guides the reader to an otherworldliness where words matter in unfathomable ways. The women instinctively form a tribal community, resembling a coven of witches that are at first sceptical, but as they realise the power of 'Oneiron' they adapt to a magical order of things: by chanting the word they proceed to the moments of their respective deaths. 


\section{Polina and Swedenborg}

In the midpoint of Oneiron one of the women, the Russian bookkeeper Polina, gives a lecture on Swedenborg. She starts the lecture using her own language, Russian, but at this point the women suddenly realise that they understand each other by a more direct communication. The lecture itself is a rather pedantic and dull exhortation, outlining Swedenborg's life and career and dwelling mostly on anecdotal and external events. It also addresses heaven's modern stance:

According to modern conceptions, Swedenborg is the first modern architect of heaven. He divided the afterlife into three parts, heaven, hell, and some sort of intermediate space, the spirit world, a place where the dead go first. There is no time in the spirit world of the dead. In the afterlife, changes in spiritual state correspond to differences in time. (Lindstedt 2015:225-6)

Without further exploring the subject, Polina proceeds to describe the corporeality and sensibility of Swedenborg's heaven, and his understanding of love as conjunction, by citing Swedenborg from her memory. After the verbatim recitation, that imparts a rather magical aura to Swedenborg's texts, Polina finally addresses whether the white void is compatible with the afterlife of Swedenborg, posing the question:

'Well now, dear women. Based on this, can you say where we are now if we even believe a part of Swedenborg's teachings?' And then Polina states a question: 'what if we vote now? Can we explain our current state using Swedenborg's celestial doctrine? ... Left hands up everyone who believes the hell hypothesis! Right, if you believe we're in heaven. And if you think Emanuel's visions are just the ravings of a deranged mind, don't raise your hands at all.' (Lindstedt 201 5:229-30)

But it was a mistake to give the women the third option:

A sullen, unwelcoming expression appears on the women's faces, the resentful, wrinkled mug of a small child who's been cheated in such a way to injure her down to her very heartstrings. In hell, in heaven: all a sham. And not a single hand goes up. (Lindstedt 2015:229-30) 
Intriguingly, the women leave it open whether they exist in a Swedenborgian afterlife or not. In the end they are not even interested in the question - a response which seems to follow from Polina's restrained and detached presentation. As the white space does not resemble anything Swedenborg has described in his afterlife, the women are left unimpressed.

Polina had begun her lecture by announcing that Swedenborg's description only 'slightly resembles where we are now' (Lindstedt 2015: 209-10, italics in original). Contrasted to the Swedenborgian afterlife, there is both relief and curse to the character of Polina. In her mundane life in Moscow she had died as an alcoholic, inebriated and plunged into a heap of snow. She was unmarried and had lived a mostly secluded life, devoting her evenings to, besides consuming liquor, reading books she loved and petting her cat. In the afterlife, however, she no longer cares for drinking, as the familiar requisites from home are lacking in her new environment. While this suggests an afterlife that blessedly eradicates addictions, which in the Swedenborgian afterlife have the nature of a purgatory for the souls, the curse would be that she finds herself in an emptiness, and in an ultimately unpleasant environment. In a Swedenborgian spirit world she would surround herself with the dear and familiar; the books she loves, her cat and her apartment, but would at the same time be desperately trying to satisfy a thirst that can't be fulfilled, as liquor there has only a representational, imaginative existence.

Polina, intriguingly, also becomes the only one who gets stuck in the white space. When in the last part of the novel the women, one by one and supported by the others, reach back to the time of their death and move forward, Polina misses her own death and has to return to the whiteness, and in this process forgets everything she has experienced with the other women. After Polina's return to the white void, a work announcement is displayed in the novel, in which is sought a new employer for her. Polina thus becomes both forgotten and doomed, replaced on earth and stuck in a discomforting limbo. 


\section{Concluding remarks}

Laura Lindstedt is both an author and a scholar of literature. ${ }^{13}$ She writes experimental literature, and Oneiron is filled with allusions, metaphors, intertextual references and different genres. Even though Oneiron became a praised and prized novel - it was awarded the Finlandia Prize, which is the most prestigious prize a novel can receive in Finland - its reception among readers at large (the common readers) was ambivalent. From one point of view it was considered incomprehensible, boring, confusing, and without a clear plot. From another it was praised as a rhizome of cultural and intertextual references. Oneiron also raised discussion or even a minor conflict on cultural appropriation. A blog entry by Ruskeat tytöt (Brown Girls) accused Lindstedt of cultural appropriation, by writing a novel dealing with women of different colour, religion, and ethnicity than herself (Hubara 2016).

For several modern and postmodern authors, esoteric, spiritual and religious texts are cultural resources. They are familiar stories, powerful narratives that can be used, re-used, circulated and re-interpreted. From a Western esotericism point of view Oneiron re-interprets themes both from the legacy of Swedenborg and from pre-Christian cosmology. As a 'secular' author Lindstedt uses ideas and thoughts from culture and occulture alike, as resources in creating literary art (see Partridge 2005). Ferguson (20 1 9: 95) emphasises that there is much to learn about the cultural impact of Western esotericism by focusing on fictional novels rather than on non-fictional works on occult or esoteric themes - as they have a much larger audience. She writes: 'Although genre fiction might sometimes strike us as sensational ersatz, or even scurrilous in its approach to esotericism, it urgently requires our attention if we are to understand how occult ideas have been transmitted, commercialised, and given meaning by and for the public' (Ferguson 2019: 95-6).

Laura Lindstedt's Oneiron. A Fantasy About the Seconds After Death can be seen as an example of a popular novel transmitting, but at the same

13 Besides of her literary work Lindstedt is also a $\mathrm{PhD}$ student in literary research. She's studying the problem of communication in Natalie Sarraute's philosophy, which influences also her literary work. One can also read Oneiron from that perspective. Communication or difficulties and gaps of communication is an important theme in the novel, in which characters speak different languages and one of them has even lost her ability to speak due to cancer. 
time, re-interpreting the ideas of the afterlife by Emanuel Swedenborg. Re-interpretation is made within the frames of the postmodern novel. The reader of Oneiron learns of Swedenborg but is not supposed to adapt his teachings. The themes Oneiron discusses concern more the problems of this world than the other world.

PhD, Adjunct Professor Tiina Mahlamäki is Lecturer in the Study of Religion at the University of Turku. She is an expert on studying fictional texts as well as biographical writing. Her main research interests are: religion and literature, gender and religion, Western esotericism, and creative writing. In her recent studies she has concentrated on Western esotericism, especially the ideas of Emanuel Swedenborg and themes associated with Rudolf Steiner's Anthroposophical Society. Her biography of the author and anthroposophist Kersti Bergroth was published in 2017. She has edited, together with Nina Kokkinen, Moderni esoteerisuus ja okkultismi Suomessa(Modern Esotericism and Occultism in Finland, Vastapaino 2020).

Tomas Mansikka, Phil.Lic., is an independent researcher in the history of religion and the history of ideas. He has published articles on Jacob Boehme and the Pietistic culture of the seventeenth and eighteenth centuries. He has also written on Emanuel Swedenborg (together with Tiina Mahlamäki) and contributed to Western Esotericism in Scandinavia (Brill 2016), Moderni esoteerisuus ja okkultismi Suomessa (Modern Esotericism and Occultism in Finland, Vastapaino 2020), and Kuvittelu ja uskonto (Imagination and Religion, SKS 2020).

\section{Bibliography}

Bauduin, Tessel M., and Henrik Johnsson, 201 8. 'Introduction: conceptualizing occult modernism', in The Occult in Modernist Art, Literature, and Cinema, eds. Tessel M. Bauduin and Henrik Johnsson (New York, Palgrave), pp. I-29

Blåfield, Matti, 2008. 'Nordenskiöld, August ( I754-I 792): Alkemist, chef för bergsbruket i Finland', in Biografiskt lexicon för Finland I. Svenska tiden, <URN:NBN:fi:sls-5227-I4I6928957833>

Bogdan, Henrik, 2020. 'Introduction: Western esotericism and literature', Lir journal, I 2, pp. 4-9, <http://ojs.ub.gu.se/ojs/index.php/LIRJ/article/ view/4878/3802> (accessed 7.6.2020)

Bulwer-Lytton, Edward, I 834. The Last Days of Pompey (London, Richard Bentley), <http://www.gutenberg.org/ebooks/1 565> (accessed 7.9.2019)

I 842. Zanoni (London, Saunders \& Otley), <http://www.gutenberg.org/ ebooks/2664> (accessed 7.9.2019)

I 87 r. Vril: The Power of the Coming Race (London, William Blackwood), <http://www.gutenberg.org/ebooks/I 95 I > (accessed 7.9.2019)

Corbett, Sara, 2009. 'The Holy Grail of the unconscious', The New York 
Times Magazine, I6.9.2009, <https://www.nytimes.com/2009/o9/20/ magazine/2ojung-t.html> (accessed 7.9.2019)

Faxneld, Per, and Mattias Fyhr (eds.), 2oro. Förborgade tecken. Esoterism i västerländsk litteratur (Stockholm, Text \& Kultur)

Ferguson, Christine, 201 9. 'What does popular fiction have to do with the occult?' in Hermes Explains: Thirty Questions about Western Esotericism, eds. Wouter J. Hanegraaff, Peter Forshaw and Marco Pasi (Amsterdam University Press), pp. 95-104

Gilhus, Ingvild Sælid, and Lisbeth Mikaelsson, 2013. 'Theosophy and popular fiction', in Handbook of the Theosophical Current, eds. Olav Hammer and Mikael Rothstein (Leiden, Brill) pp. 453-72

Horn, Friedemann, I 997. Schelling and Swedenborg. Mysticism and German Idealism, Swedenborg Studies, 6 (West Chester, PA, Swedenborg Foundation)

Hubara, Koko, 2o r6. 'O(t)heiron', in Ruskeat tytöt [blog], <https://www.lily.fi/ blogit/ruskeat-tytot/otheiron/> (accessed 7.9.2019)

Jung, C. G., 2009. The Red Book: Liber Novus, ed. Sonu Shamdasani (Carpinteria, Philemon Foundation)

Kokkinen, Nina, Tiina Mahlamäki, and Maarit Leskelä-Kärki 202o. 'Esoteerisuus taiteessa ja kirjallisuudessa', in Moderni esoteerisuus ja okkultismi Suomessa, eds. Tiina Mahlamäki and Nina Kokkinen (Tampere, Vastapaino), pp. $22 \mathrm{I}-45$

Lachman, Gary, 2009. Emanuel Swedenborg: An Introduction to his Life and Ideas (New York, Penguin)

Lindstedt, Laura, 20 I 5. Oneiron. Fantasia kuolemanjälkeisistä sekunneista (Helsinki, Teos)

201 8. Oneiron. A Fantasy About the Seconds After Death, transl. Owen F. Witesman (London, Oneworld Publications)

Mahlamäki, Tiina, 2oro. 'Seitsemän veljeksen salattu maa. Emanuel Swedenborgin ideoiden läsnäolo Aleksis Kiven Seitsemän veljestä-teoksessa', Sananjalka, 52 , pp. I6 $63-80$

2OI 4. "A touch of the spiritual world?" An anthroposophical core in the life and work of Kersti Bergroth (1886-1975)', in Finnish Women Making Religion: Between Ancestors to Angels, eds. Terhi Utriainen and Päivi Salmesvuori (Basingstoke, Palgrave Macmillan), pp. I03-2 I

2017. Kaikki maallinen on vain vertauskuvaa. Kirjailija Kersti Bergrothin elämäkerta (Helsinki, Kulttuuriosuuskunta Partuuna)

20 18. 'A relation of Swedenborgianism and anthroposophy: the case of the Finnish author Kersti Bergroth and her novel The Living and the Dead', Approaching Religion, 8(1), pp. 69-78, doi: <https://doi.org/ıo.30664/ ar.66723>

Mahlamäki, Tiina, and Tomas Mansikka, 2o ıо. 'Remarks on Swedenborgian elements in the literary production of Johan Ludvig Runeberg', Temenos: 
Nordic Journal of Comparative Religion, 46(I), pp. 73-99, <https://journal.fi/ temenos/article/view/6942> (accessed 7.9.2019)

-20I3. "His visions have captured my thoughts": Emanuel Swedenborg in the newspapers and national literature in I 9th century Finland', in Emanuel Swedenborg. Exploring a 'World Memory': Context, Content, Contribution, ed. Karl Grandin (Stockholm, The Center for the History of Sciences, The Royal Swedish Academy of Sciences), pp. 296-3 I I

McDannell, Colleen, and Bernhard Lang, 200I (I 988). Heaven: A History (New Haven, Yale University Press)

McNeilly, Stephen (ed.), 2005. Between Method and Madness: Essays on Swedenborg and Literature (London, The Swedenborg Society)

Oneiromantien, eller Konsten at tyda drömar, förra delen (Stockholm, Stolpiska tryckeriet, I 783), <http://www.alvin-portal.org/alvin/view.jsf ?pid=alvin-record $\% 3$ A roo979\&dswid=3 I03 $>$ (accessed 7.9.20 I9)

Oneiromantien, eller Konsten at tyda drömar, andra delen (Stockholm, Stolpiska tryckeriet, I 783), <http://www.alvin-portal.org/alvin/view.jsf?pid=alvin-record\%3 A roo980\&dswid=64I $3>$ (accessed 7.9.2019)

Paley, Morton D., I 979. “A new heaven is begun”: William Blake and Swedenborgianism', Blake/An Illustrated Quarterly, I3 (2), pp. 64-90 <http:// bq.blakearchive.org/I 3.2.paley> (accessed 30.3.2020)

Partridge, Christopher, 2005. The Re-Enchantment of the West, vol. I (London, Bloomsbury)

Råback, Jenni, 20 I 8. Jenni Råback reviews Oneiron by Laura Lindstedt. Asymptote, $<$ https://www.asymptotejournal.com/criticism/laura-lindstedt-oneiron/> (accessed 30.3.2020)

Ramstedt, Tommy, 201 8. Knowledge and Identity within the Finnish Fringe-Knowledge Scene (Åbo Akademi), <http://urn.fi/URN:ISBN:978-95 I-765-9i 6-I >

Ramstedt, Tommy, and Marcus Moberg, 2020. 'Esoteerisuus ja populaarikulttuuri', in Moderni esoteerisuus ja okkultismi Suomessa, eds. Tiina Mahlamäki and Nina Kokkinen (Tampere, Vastapaino), pp. 247-67

Rein, Gabriel, I 939. 'Porthan ja "valon viholliset”', Historiallinen arkisto, 46, pp. 103-I 8

Schuchard, Marsha Keith, I 992. 'The secret masonic history of Blake’s Swedenborgian Society', Blake: An Illustrated Quarterly, 26(2), pp. 40-5 I , <http:// bq.blakearchive.org/26.2.schuchard>

Siukonen, Jyrki, 2000. 'Jälkilehtiä. Swedenborgin jälkivaikutus', in Clavis Hieroglyphica, Emanuel Swedenborg, transl. and introduction by Jyrki Siukonen (Helsinki, Gaudeamus), pp. 88-i I 2

Sjödén, Karl-Erik, I 995. 'Swedenborg in France', The New Philosophy, 98(I-2), pp. $63-98$

Smithson, I. H. (ed.), I 84 I. Documents Concerning the Life and Character of Emanuel Swedenborg, Late Member of the House of Nobles in the Royal Diet of 
Sweden, Assessor of the Royal Board of Mines, Fellow of the Royal Society of Upsala, and of the Royal Academy of Sciences of Stockholm, and Corresponding Member of the Academy of Sciences of St. Petersburg, collected by Dr. J. F. I. Tafel (Manchester, Joseph Hayward, Market-Place)

Swedenborg, Emanuel, I 988 ( I 745). Om Guds dyrkan och kärleken till Gud, transl. Ritva Jonsson (Lund, Natur och Kultur)

2000. Clavis Hieroglyphica, transl. and introduction by Jyrki Siukonen (Helsinki, Gaudeamus)

2008 (1749-56). Secrets of Heaven, vol. I: . New Century Edition, transl. Lisa Hyatt Cooper, <https://swedenborg.com/product/secrets-heaven- Ince/> (accessed 3.2.2018)

2010 ( 1758 ). Heaven and Hell. The Portable New Century Edition, transl. George F. Dole, < https://swedenborg.com/wp-content/uploads/201 5/o8/ NCE_HeavenandHell_portable.pdf> (accessed 3.2.2018)

Thorpe, Lucas, 20 I I. 'The realm of ends as a community of spirits: Kant and Swedenborg on the Kingdom of Heaven and the cleansing of the doors of perception', Heythrop Journal, 52 (I), pp. 52-75

Tweed, Thomas, 2006. Crossing and Dwelling: A Theory of Religion (Cambridge, MA, Harvard University Press)

Versluis, Arthur, 2004. Restoring Paradise: Western Esotericism, Literature, Art, and Consciousness (Albany, State University of New York Press)

Williams-Hogan, Jane, r 998. 'The place of Emanuel Swedenborg in modern Western esotericism', in Western Esotericism and the Science of Religion: Selected Papers presented at the $17^{\text {th }}$ Congress of the International Association for the History of Religions, Mexico City 1995, eds. Antoine Faivre and Wouter J. Hanegraaff (Leuven, Peeters), pp. $201-52$ 2005. 'Emanuel Swedenborg', in Encyclopedia of Religion, vol. I3, 2nd edn, ed. Lindsay Jones (Detroit, MacMillan), pp. 8898-900

2008. 'The place of Emanuel Swedenborg in the spiritual saga of Scandinavia', in Western Esotericism, ed. Tore Ahlbäck, Scripta Instituti Donneriani Aboensis, 2o, (Åbo, Donner Institute), pp. 254-8o, doi: <https://doi.org/Io.30674/scripta.67339> 20 r 6. 'Swedenborgianism in Scandinavia', in Western Esotericism in Scandinavia, eds. Henrik Bogdan and Olav Hammer (Leiden, Brill), pp. 534-53 